\title{
ІНФАНТИЛЬНА ПОВЕДІНКА СТУДЕНТСЬКОЇ МОЛОДІ: ОСНОВНІ ПОКАЗНИКИ ТА ОСОБЛИВОСТІ ПРОЯВУ
}

\begin{abstract}
У статті репрезентуються результати теоретичного та емпіричного дослідження проблеми інфантильності. Розкрито зміст поняття «інфантильність». Визначено соиіально-психологічний ракурс аналізу проблеми інфантильності особистості, сутності та структури даного явища, визначено показники інфантильної поведінки особистості та чинники їх формування. Висвітлено результати емпіричного дослідження основних проявів інфантильної поведінки студентської молоді. Зроблено висновок, щя досліджуваним не властивий патологічний прояв інфантильних рис.
\end{abstract}

Ключові слова: інфантильність, дитячість, зрілість, незрілість, залежна поведінка, затримка розвитку.

The essence of the concept of infantilizm as a form of dependent behavior that is characterized by saving childhood features that prevent successful development and personality self-actualization is revealed in the article.

The main theoretical approaches to the nature and structure of this phenomenon are analysed. Based on the analysis four main approaches are distilled: psychoanalytic - considers infantilizm as a manifestation of the unconscious and immaturity of forms of mental protection of personality; humanistic - interprets infantile person, not like self-actualised, which inherent signs of immaturity; family system psychotherapy - treats infantilizm from the position of family systems where deficit or violation of its components is the cause of infantile manifestations in behavior and activity approach, which gives understanding of infantilizm as a disorder process of involution child's development.

Defined indicators of the infantile person's behavior and factors of their formation. The main indicators of infantile behavior: dependency, children's logic and imperfections of thinking, lack of initiative in decision-making, impulsivity, desire for inheritance, emotional instability, egocentrism, weakness volitional installations, conformity, rigidnost behavior, shyness, timidity, uncertainty, instability of interest level of self-esteem and others.

The main factors of infantile behavior: congenital disorders of internal development; communicable diseases moved in the early age; intrapersonal conflict; violation in the parameters of family systems, confluences, protective mechanism regression and immaturity of personality.

The results of empirical research manifestations of infantile behavior among the students are highlited. It is found out that the most pronounced manifestations of infantile behavior among modern students are: lack of initiative in making decisions (50\%), emotional instability (40\%) and conformability (40\%). Inherent childness and storeys thinking, naive (37\%), flexibility and rigidity behavior (33\%), egocentrism are less distinctive features. The least pronounced manifestation of infantility was a high level of self-esteem (13\%).

Keywords: infantility, dependent behavior, involution child development, childishness, immaturity, conformability.

Актуальність дослідження. Відомо, що саме молоді люди чинять потужний вплив на перебіг соціального життя суспільства, його інноваційність та прогресивність. Для того, щоб бути активним творцем не лише власних, а й соціальних реалій, визначати життєві цілі, досягати мети, зростати особистісно та професійно - необхідно мати розвинуте почуття відповідальності за себе та інших; прагнути самовдосконалення; бути незалежним від думки соціального 
оточення; вірити у власні сили; прагнути, та досягати успіху. Тому, на даному етапі суспільного життя вкрай необхідним є розвиток якостей зрілої особистості, оскільки вони є рушійною силою становлення молодого покоління.

На жаль, у нашому сучасному соціумі, ми все частіше спостерігаємо, серед молоді, прояви зниження ініціативності, зміни ціннісних орієнтацій, невпевненість, пасивність, безвідповідальність, нерішучість, замкнутість, байдужість, несамостійність, безпорадність, егоїзм, корисливість та особистісну незрілість. Результатом яких стає формування відповідних життєвих пріоритетів та поведінкових паттернів: орієнтація на стратегію споживання, а не творення; відсутність прагнення «зануритися» в проблему; відсутність бажання до серйозної й відповідальної праці; пошуки легкої роботи та заробітку; байдуже ставлення до власної успішності; залежність від думки оточення; несамостійність в ухваленні рішень; надмірна імпульсивність та ін.

Цілком зрозуміло, що такі орієнтації та пріоритети перешкоджають успішному розвитку, самоактуалізації та формуванню особистої зрілості, які так необхідні нашому суспільству.

Метою статті $є$ визначення основних показників та особливостей прояву інфантильної поведінки сучасної студентської молоді.

Завдання: 1. Визначити соціально-психологічний ракурс аналізу проблеми інфантильності особистості та визначити основні показники інфантильної поведінки. 2. Проаналізувати результати емпіричного дослідження особливостей прояву інфантильної поведінки у студентів.

Методи і методологія дослідження: Теоретичні методи: узагальнення; порівняння; критичне осмислення інформації; класифікація та систематизація для впорядкування та узагальнення термінології; аналіз та синтез. Емпіричні методи: стандартизовані психологічні методики: «Дослідження імпульсивності» Пашукова; методика та тест егоцентричних асоціацій (TEA); тест самоактуалізації (CAT) М. Кроз, Л. Гозман та «16 RF- опитувальник» Р. Кеттела. Графічні методи: побудова графіків та гістаграм.

Аналіз останніх досліджень. Інфантильність, як проблему «соціальної зрілості» особистості розглядали Б. Ананьєв, Г. Андрєєва, І. Кон, Ю. Косолапов, В. Могун, Л. Виготський, В. Ковальов, В. Лебединський, А. Гурьєва, К. Платонов, А. Личко та ін. Дослідженням причин, чинників виникнення інфантильних рис в особистості займалися також зарубіжні науковці Г. Антон, 3. Фрейд, Э. Крепелін, Г. Штуте, Э. Ласег, Р. Корбо та ін. Так, К. Абрахам, Е. Джонс, 3. Фрейд, К. Юнг, Г. Гуг-Гельмут розглядали інфантильність з точки зору прояву несвідомого і незрілості форм психічних захистів особистості. 3-поміж наукових досліджень слід відзначити підходи які пояснюють проблему інфантильності з точки зору затримки чи розладу психічного розвитку особистості. Так, Р. Корбо трактує інфантильність з погляду затримки афективного розвитку. Інфантильніть як розлад процесу інволюції дитячого розвитку розглядає Л. Виготський, а як форму порушення інтелектуальної діяльністі у рамках затриманого темпу психічного розвитку I. Шенфиль, Г. Сухарьова, М. Буянов. Водночас, на сьогодні, в науковій літературі існує декілька підходів щодо 
визначення даного поняття, але питання проявів інфантильної поведінки сучасної молоді, та їі чинників залишається, як ніколи, актуальним.

Виклад основних положень. Поняття «інфанти́льність», або «інфантилізм» (від лат. infantilis - дитячий) - відсталість у розвитку, яка характеризується збереженням у людини фізичних або психічних рис дитячого віку [4]. У переносному сенсі - інфантильність характеризується як прояв дитячого підходу в різних життєвих сферах, невміння приймати усвідомлені рішення i небажання брати зобов'язання на себе. Деякі дослідники трактують феномен інфантильності, як прояв особистості, тимчасовий стан, за якого суб'єкт до певної міри використовує інфантильну поведінку як механізм захисту [5].

Аналіз наявних досліджень 3 питань інфантильності дозволив виокремити основні підходи та точки зору щодо даної проблеми. Представники психоаналітичного підходу 3. Фройд, К. Хорні, К. Юнг, О. Кернберг, Г. Салліван, Е. Фромм та А. Адлер пояснювали даний феномен, як фіксацію на певній стадії розвитку особистості. Зокрема 3. Фрейд стверджував, що інфантильною реакцією є механізм регресії, який характеризується поверненням на більш ранній рівень розвитку, або до способу вираження дій, емоцій та почуттів, які більш властиві дітям [9, с. 86]. На думку К. Юнга інфантильність це залежність, яка пригнічує розвиток особистості, «тому, що ніщо так не перешкоджає розвитку, як застигання в несвідомому, можна навіть сказати, у психічно ембріональному стані» [2].

К. Хорні пояснює інфантильні риси як результат внутрішньоособистісного конфлікту. Виділяє інфантильну спрямованість особистості в трьох напрямах: «рух до людей» - «поступливий тип», якому характерна потреба в любові, схваленні та людях, які беруть всю відповідальність та зобов'язання на себе; «рух проти людей», що має прояви бунтарської поведінки, а також «рух від людей» де ознаками є нав'язливий та негнучкий характер. Отже, всі три типи інфантильної спрямованості особи є, по суті, формами залежної поведінки.

Також цікавими є погляди представників психоаналітичного підходу, щодо виокремлення основних чинників та показників інфантильної людини. К. Юнг в якості причин визначає неврози та незадоволеність собою. До інфантильних проявів відносить егоїзм, пасивність та інші. На думку 3. Фрейда причиною слугує внутрішньоособистісний конфлікт «практичні вчення про витіснення інфантильної сексуальності» [9]. О. Кернберг розглядає такі показники інфантильної особистості: дифузна емоційна лабільність, недиференційовані відносини з іншими та поверховість емоцій. На його думку, інфантильна особистість «надмірно ідентифікує себе з іншими та проектує на них свої нереалістичні фантазії й наміри» [6].

Отож, згідно психоаналітичного підходу, інфантильність - це прояви несвідомого й незрілості форм психічних захистів особистості.

3 цілком інших позицій розглядають даний феномен представники гуманістичного підходу. Так, А. Маслоу порівнював інфантильність з само актуалізацією. Вважав, що самоактуалізованій особистості характерні «зрілі риси», 
такі як автономність й відповідальність, а інфантильній «хворі риси», що мають протилежні ознаки, які проявляються у схильності відчувати себе слабкими i безпорадними [10, с. 58]. Ф. Перлз зазначав, що інфантильній людині властивий такий захисний механізм як конфлюенція (злиття), який полягає в «розмиванні» психологічних меж. Тобто в особи відсутнє усвідомлення де «Я», а де «Інший» [10, с. 52]. До показників він відніс неможливость розрізнити власні потреби / бажання та залежність від інших, причиною якої і є конфлюенція.

Отже, гуманістичний підхід зосереджує увагу на зрілості особистості, а не на інфантильності, тому, важливим завданням стає розвиток особистісних та професійних якостей, формування знань та навичок, що є шляхом до самоактуалізації й подолання інфантильності.

Представники сімейної системної психотерапії М. Палаццолі, Д. Чеккіні, Д. Хейлі, С. Минухін, розглядали інфантильність як чинник дефіциту, порушень в параметрах сімейної системи. Сім'я, на їхню думку, є єдиним цілим, взаємопов'язаним біологічним і психологічним організмом, порушення в якій чинить руйнівний вплив не тільки на одну особу, а й на всю сім'ю. До чинників, що формують інфантильність особистості відносять: несерйозне ставлення батьків в дитинстві; прийняття рішень, розв’язання завдань, проблем за підлітка; надмірний контроль, що обмежує підлітка (але не дитину) у свободі; патологічне злиття сім’і, коли потреби, бажання, погляди іiі членів спільні. Дитина, що виростає в патологічно злитій сім’ї, емоційно та фізично прив'язана до рідних, не здатна приймати власні рішення, робити самостійні кроки, не усвідомлює чого вона хоче i як цього досягти, завжди очікує підтримки, схвалення сім’і, отже - стає залежною [3, с. 23].

Вище сказане дає підстави стверджувати, що інфантильна поведінка може формуватися в результаті наявного дефіциту сімейної системи. У випадках неправильного розподілу ролей, авторитарного та потурального стилю ви-

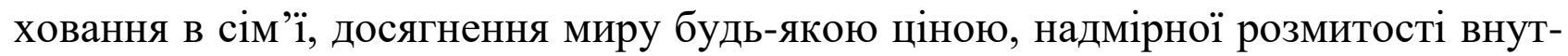
рішніх кордонів та жорсткості зовнішніх, дефіциту або ригідності сімейних правил, стійких способів поведінки незалежно від їхньої доцільності та свідомому наслідуванні авторитету.

Таким чином, у межах сімейного системного підходу інфантильність трактується з позиції сімейної системи, де дефіцит або порушення її складових є причиною інфантильних проявів у поведінці: несамостійність, безвідповідальність, неорганізованість, безініціативність, низька витривалість до психічних навантажень, потреба в опіці й схвалені та ін.

Аналіз праць представників діяльнісного підхіду дає розуміння інфантильності як розладу процесу інволюції дитячого розвитку [1]. Л. Виготський під інфантильністю розуміє порушення темпу якісної перебудови психічних функцій (мислення, уваги, пам’яті, моторики), при якому психіка зберігається на більш ранньому віці [7].

Загалом, вище висвітлені наукові підходи трактують інфантильність як багатогранний феномен, який $\epsilon$ формою залежної поведінки, пригнічує розвиток особистості та деструктивно впливає не тільки на емоційно-вольову та 
ціннісно-смислову сфери, а й на когнітивну та поведінкову сфери особистості. Відтак, чинники виникнення інфантильної поведінки умовно можна поділити на внутрішні та зовнішні. Внутрішні включають в себе внутрішньоособисні конфлікти, незадоволеність собою, фізичні ураження, невміння співвідносити свої вчинки з реальною ситуацією. До зовнішніх чинників слід віднести: вплив оточення, несерйозне ставлення батьків до дитини, патологічне навіювання; надмірний контроль, що обмежує підлітка у свободі; авторитарний та потуральний стиль виховання; надмірний захист та опіка щодо особи.

В основу нашого дослідження покладені теоретичні положення гуманістичного підходу щодо самоактуалізованої особистості, якій характерні «зрілі риси», такі як автономність й відповідальність, а інфантильній «хворі риси», що мають протилежні ознаки, які проявляються у схильності відчувати себе слабкими і безпорадними.

Діагностика інфантильних проявів поведінки сучасної студентської молоді здійснювалась нами за допомогою тесту самоактуалізації (САТ) М. Кроз, Л. Гозман [8], «Дослідження імпульсивності» Пашукова [8], тест егоцентричних асоціацій (TEA) [8] та «16 RF-опитувальник» Р. Кеттела [8]. У дослідженні, яке проводилось у 2018-2019 рр., прийняло участь 30 молодих людей, віком 19-20 років, які навчаються у ВНЗ України.

У досліджені нами брались до уваги лише окремі показники, які характерні інфантильній поведінці особистості, а саме: конформність; гнучкість поведінки; емоційна нестійкість; імпульсивність; слабкі вольові установки; егоентричність; безініціативність у прийнятті рішень; не реалістичність поглядів, переконань; рівень самооцінки. За допомогою даного діагностичного інструментарію та означених показників ми визначили наявність інфантильних проявів притаманних поведінці студентської молоді, та рівень їхньої вираженості.

Результати дослідження засвідчили, що більшість досліджуваних (60\%) проявляють середній та вище середнього рівень конформності, що свідчить про певну їх схильність до зовнішнього впливу. Отже, вони більше схильні керуватися власними принципами та мотивами, володіють внутрішньою підтримкою та вільні у своєму виборі. Це, у свою чергу, позитивно впливає на формування незалежної особистості, яка знає чого вона хоче і як цього досягти.

Варто зазначити, що жодному респонденту не властивий низький рівень конформності, що дає підстави говорити про відсутність цілком незалежних, самостійних осіб, які не потребують схвалення, підтримки зі сторони, володіють високим рівнем самоконтролю та емоційною стійкістю. Проте, з огляду на вікову категорію респондентів, отриманий результат, безсумнівно, допустимий, оскільки досліджувані знаходяться на етапі особистісного та професійного самовизначення, тобто переживають кризу ідентичності.

Для $40 \%$ опитаних характерний високий рівень конформності, що свідчить про їхню прив'язаність до групи, орієнтацію на групову думку, потребу в постійній підтримці та схваленні. Дана характеристика респондентів цілком відображає поведінку та потреби інфантильних осіб. 
Хотілося 6 зазначити, що 33\% студентів, за показником гручності поведінки, показали низький та нижче середнього рівні. Це свідчить про те, що респонденти складно адаптуються до ситуації (неспроможні самостійно виходити 3 складних ситуацій) та проявляють ригідність поведінки, незмінність інтересів і установок, що виявляється у вимогливості та впертості. Проте, слід зазначити, що високий рівень гнучкості поведінки, який виявлений у $10 \%$ студентів, також може бути свідченням інфантильної поведінки досліджуваних, якщо проявлятиметься у пристосовницькій стратегії поведінки. Важливо зазначити, що для формування зрілої особистості за показником гнучкості поведінки необхідний рівень в межах середнього, який, власне, діагностовано у $56 \%$ студентів.

За результатами дослідження, вираженим інфантильним проявом, що притаманний $40 \%$ опитаним є низька емоційна стійкість. Ознаками якої є труднощі під час стримування емоцій, а відповідно і дій, вразливість, висока чутливість та емоційні спалахи, які залежать від обставин в яких перебуває індивід. Висвітлені результати знаходять підтвердження за допомогою співставлення з критерієм імпульсивність, де $33 \%$ студентів проявили високий рівень. Однією з причин імпульсивності в молоді часто $є$ вплив зовнішніх обставин.

Також $20 \%$ студентам притаманний середній рівень емоційної стійкості, а у $40 \%$ студентів виявлено емоційну зрілість. Це, безперечно, позитивний прояв, адже в юнацькому віці формування емоційно зрілих рис - це складний процес, який обумовлений самоконтролем не зважаючи на емоційні переживання та зовнішні фактори.

Дослідження показало, що 30\% опитуваних мають високий рівень егоцентризму, $50 \%$ середній, а $20 \%$ - низький рівень. Високі показники егоцентризму свідчать про нехтування потребами інших, зосередженість на власних почуттях й інтересах та формування стосунків 3 іншими через призму особливого сприйняття на грунті власного уявлення про реальність. Результати, які підтверджують надання переваги власним нереалістичним уявленням, (що характерно для поведінки інфантильних осіб), є результати за показником реалістичність поглядів, де $37 \%$ опитаних властивий низький рівень, тобто вони орієнтовані на власні дитячі погляди та переконання, що є егоцентричним.

За показником відсутность ініціативи у студентів отримано наступі результати: високий рівень притаманний $50 \%$, середній $13 \%$, а низький рівень $37 \%$ досліджуваних. Високий рівень безініціативності виявлено у половини опитаних, що свідчить про пасивність дій та перекидання відповідальності на інших. Їхня безініціативність $є$ перешкодою на шляху до самоактуалізації тому, безперечно, потребує оптимізації.

Виявлено, що $33 \%$ опитаних володіють високим рівнем вольових установок, що свідчить про дисциплінованість та вміння саморегулювати свою діяльність й психічні процеси. Поряд 3 цим, 20\% мають низький рівень та змушені докладати великих зусиль для досягнення цілей, їм характерна слабка витримка і самовладання. 
Дослідження також показало, що 13\% студентів мають високий рівень самооцінки, що проявляється у вигляді надмірної вимогливості до оточуючих 3 метою задоволення їх потреб та бажань. Разом з тим, 57\% - недооцінюють себе, самокритичні та невпевнені, а це перешкоджає їхньому розвитку та становленню як зрілих особистостей.

За допомогою проведення процедури ранжування встановлено, що серед показників, кожен з яких відповідає певному прояву інфантильної поведінки, перше місце за частотою прояву займає показник «безініціативність у прийнятті рішень» $-50 \%$. Чинником вираження даної ознаки може слугувати відчуття страху та болісне небажання приймати рішення на основі минулого досвіду (Див. рис. 1).

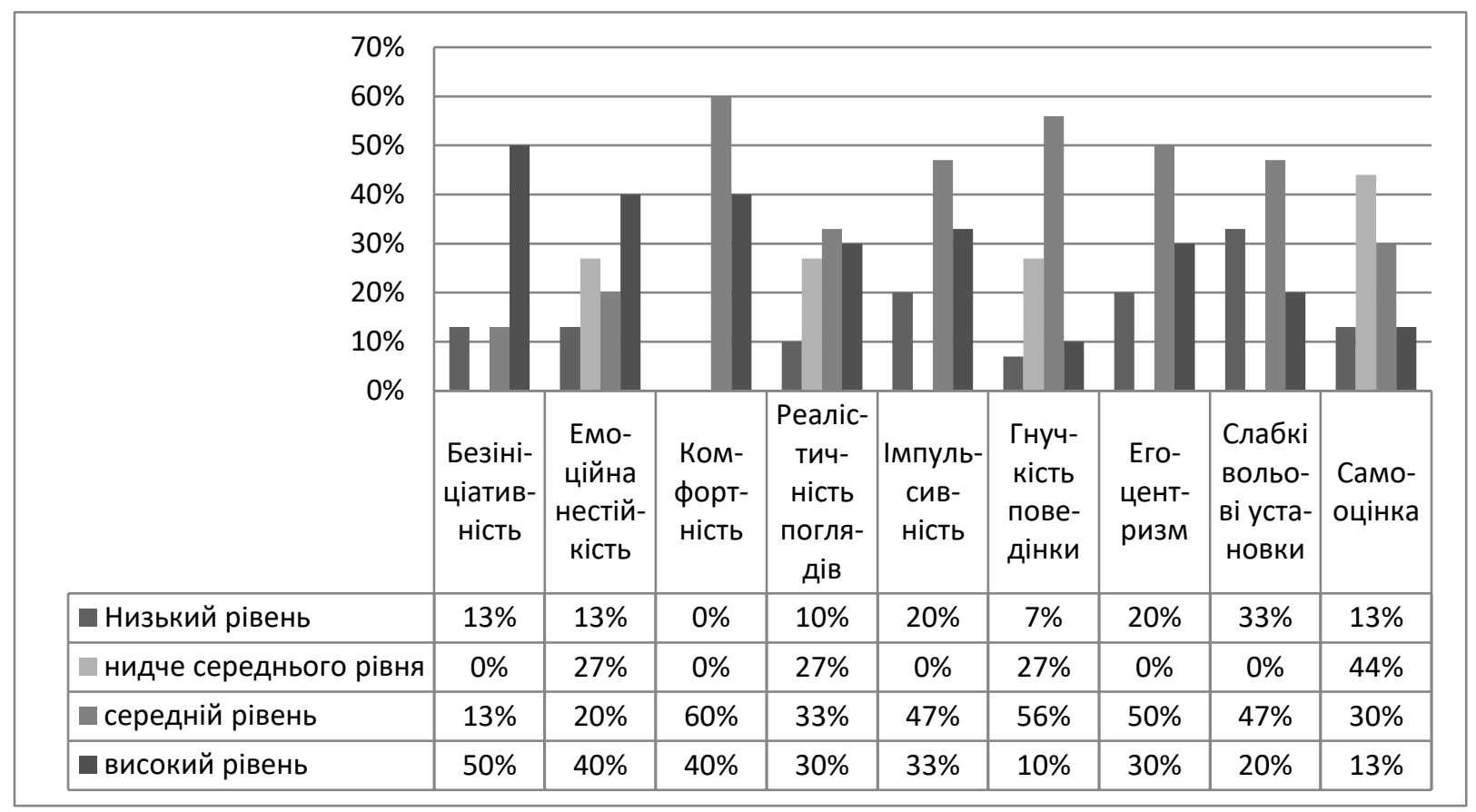

Рис. 1. Результати прояву інфантильної поведінки студентської молоді за основними показниками (у\%)

На другому місці показник «гнучкість поведінки» - (43\%). Це свідчить про незмінність інтересів і установок. Проте варто зауважити, що установки таких осіб поверхневі, сформувалися без глибокого аналізу, але вони готові їх сліпо відстоювати вимагати виконання бажаних дій. На третьому місці показник «емоційна нестійкість» (40\%). Четверту позицію займає конформність, висока вираженість якої характерна 40\% досліджуваним. Чинником може бути патологічне злиття, пов'язування своїх потреб, емоцій та дій з іншими людьми, а також як результат авторитарного стилю виховання. П'яте місце належить показникові «реалістичність поглядів» - 37\% опитаних. Низький рівень вираженості даного показника в опитуваних свідчить про дитяче мислення, схильність до фантазування, поверховість мислення та наївність.

Шоста позиція - показник «імпульсивність», високий рівень якої властивий (34\%). Наступним за поведінковим проявом є егоцентризм виявлений у $30 \%$ респондентів. Чинником якого може слугувати, потурання ще в дитинстві. 
Восьме місце за враженістю займає показник «слабкі вольові установки», який проявляється у $20 \%$. Чинниками можуть виступати незрілість особистості, якій характерне почуття незахищеності, ідеалізація соціальної реальності, занижена самокритичність. Іншими чинниками можуть бути систематичне ставлення респондента в рамки, обмеження в прийнятті рішень, що веде до нерозвиненості емоційно-вольової сфери. Найменш вираженою ознакою серед опитуваних є високий рівень самооцінки (13\%).

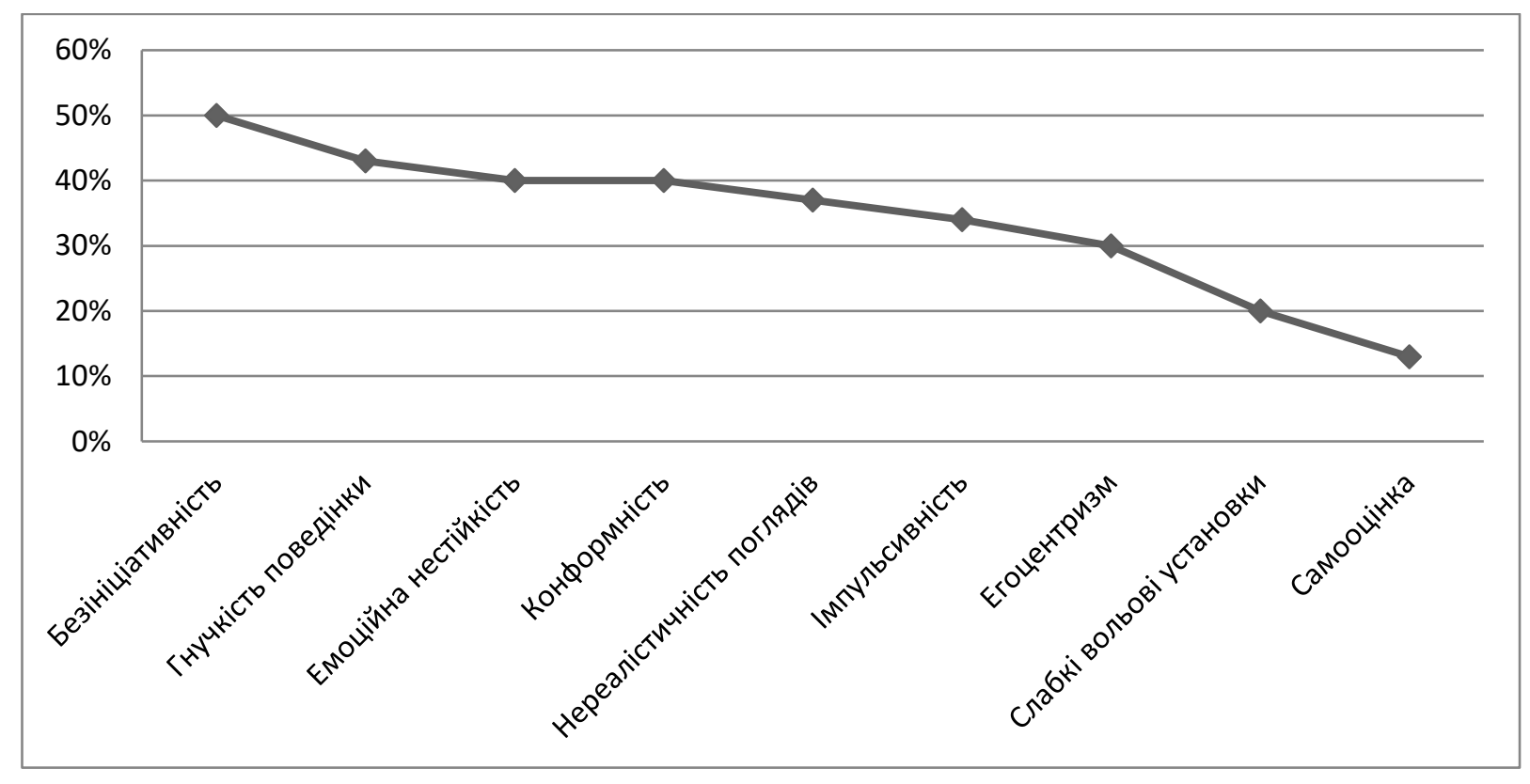

Рис. 2. Графік прояву показників інфантильної поведінки студентської молоді за результатами ранжування (у\%)

Висновки. Інфантильність $\epsilon$ формою залежної поведінки, що характеризується збереженням рис дитячого віку, які перешкоджають успішному розвитку та самоактуалізації особистості.

Інфантильність $є$ багатогранним феноменом, до основних чинників формування якого, на нашу думку, належать: вроджені патології внутрішнього розвитку; гормональне порушення раннього віку; інфекційні захворювання, які перенесені в ранньому віці; психологічний тиск на дітей; внутрішньоособистісний конфлікт; відчуття страху та болісне небажання приймати рішення на основі минулого досвіду; порушення в параметрах сімейної системи; конфлюенція; захисний механізм регресії та незрілість особистості.

Основними показниками інфантильної особистості є: несамостійність; дитяча логіка і недосконалість мислення; недостатність практичних навичок; відсутність ініціативності у прийнятті рішень; низька витривалість до психічних навантажень; підвищена сугестивність; імпульсивність; прагнення до наслідування; емоційна нестійкість; егоцентризм; слабкість вольових установок; легке відволікання; конформність; лабільність настрою; жива уява; сором'язливість; боязкість; невпевненість; схильність до скрупульозності; високий рівень самооцінки; підвищена виснаженість; нестійкість інтересів та інші. 
За результатами проведеного емпіричного дослідження серед студентської молоді встановлено, що найбільш вираженими показниками інфантильної поведінки, притаманної сучасним студентам $\epsilon$ : безініціативність $(50 \%)$; гнучкість поведінки (43\%) емоційна нестійкість (40\%) та конформність (40\%). Менш вираженими $є$ не реалістичність поглядів (37\%), імпульсивність (34\%), егоцентризм - (30\%) та слабкі вольові установки - (20\%). Найменш вираженою ознакою інфантильності є висока самооцінка (13\%). Загалом, досліджуваним не властивий патологічний прояв інфантильної поведінки. А оскільки високий та низький рівень самооцінки й відсутність ініціативи спостерігалася у більшої половини досліджуваних студентів, вважаємо доречним застосування відповідних методик, вправ, завдань, психологічних рекомендації, які допоможуть ефективно подолати наявні прояви інфантильної поведінки студентів.

Зважаючи на те, що студентська молодь живе у сучасному суспільстві, для якого характерна динамічність, нестабільність і трансформативність, переживання різноманітних криз результати дослідження $\epsilon$ цілком закономірними.

Перспективи подальших досліджень у цьому напрямку вбачаємо у вивченні шляхів оптимізації інфантильної поведінки сучасної студентської молоді, формуванні психологічно зрілої особистості Зокрема, створення програми корекційно-розвивальних тренінгів для студентів із проявами інфантильної поведінки.

1. Александрова А. С. Социально-психологические условия преодоления инфантилизма у беззаботной молодежи. Москва, 2006. $250 \mathrm{c}$.

2. Бурянов М. П. Психологічний інфантилізм і сучасні проблеми. Журнал нервопатології $i$ ncuxiampiï. 1999. № 1. С. 158-199.

3. Варга А. Я. Системная семейная терапия. Краткий лекционный курс. Санкт-Петербург : Речь, 2001. С. 21-35.

4. Дерев'яних Е. А. Соціальний інфантилізм в молодіжному середовищі. Наукове товариство студентів XXI століття. Громадські науки : зб. ст. по мат. XXV Міжннар. студ. наук.-практ. конф. № 10 (24). URL: http://sibac.info/archive/social/10(24).pdf (дата звернення: 04.11.2016).

5. Єфремова. Г. З. Соціальний інфантилізм студентської молоді як фактор протистояння сучасному суспільству. Інтернет журнал «Науко введення». 2014. № 6. URL: http://naukovedenie.ru/PDF/09PVN614.pdf.

6. Єфремова Г. І. Соціально психологічні чинники інфантилізму в безробітньої молоді, психологічні механізми подолання. Київ : Академвидав, 2008. 154 с.

7. Инфантилизм социальный. Словарь практического психолога. URL: http://www.psdict.ru/ 15.php.

8. Смирнова Е. Т. Экспресс-психодиагностика. Введение в целостную психологию. Методики и тесты. Самара : Издательский дом «Бахрах», 2005. С. 320.

9. Фрейд А. Введение в детский психоанализ. Норма и патология детского развития. «Я» $u$ механизмы защиты : сборник. Минск : Попурри, 2010. С. 86.

10. Штепа О. С. Особистісна зрілість : монографія. 2008. С. 52-58.

\section{References}

1. Aleksandrova, A.S. (2006). Sotsyalno-psykholohycheskye uslovyia preodolenyia ynfantylyzma u bezzabotnoi molodezhy. Moskva. [in Russian]. 
2. Burianov, M.P. (1999). Psykholohichnyi infantylizm i suchasni problemy. Zhurnal nervopatolohii i psykhiatrii, 1, 158-199. [in Ukrainian].

3. Varha, A.Ya. (2001). Systemnaia semeinaia terapyia. Kratkyi lektsyonnyi kurs. SanktPeterburh: Rech. [in Russian].

4. Derevianykh, E.A. Sotsialnyi infantylizm v molodizhnomu seredovyshchi. Naukove tovarystvo studentiv XXI stolittia. Hromadski nauky: zb. st. po mat. XXV Mizhnar. stud. nauk.-prakt. konf., 10 (24). Retrieved from http://sibac.info/archive/social/10(24).pdf (data zvernennia: 04.11.2016) [in Ukrainian].

5. Iefremova, H.Z. (2014). Sotsialnyi infantylizm studentskoi molodi yak faktor protystoiannia suchasnomu suspilstvu. Internet zhurnal «Nauko vvedennia», 6. Retrieved from http://naukovedenie.ru/PDF/09PVN614.pdf. [in Ukrainian].

6. Iefremova, H.I. (2008). Sotsialno psykholohichni chynnyky infantylizmu v bezrobitnoi molodi, psykholohichni mekhanizmy podolannia. Kyiv: Akademvydav. [in Ukrainian].

7. Infantylyzm sotsyalnyi. Slovar praktycheskoho psykholoha. Retrieved from http://www. psdict.ru/ 15.php. [in Ukrainian].

8. Smyrnova, E.T. (2005). Ekspress-psykhodyahnostyka. Vvedenye v tselostnuiu psykholohyiu. Metodyky y testy. Samara: Yzdatelskyi dom «Bakhrakh. [in Russian].

9. Freid, A. (2010). Vvedenye v detskyi psykhoanalyz. Norma y patolohyia detskoho razvytyia. «Ia» y mekhanyzmy zashchyty: sbornyk. Mynsk: Popurry. [in Russian].

10. Shtepa, O.S. (2008). Osobystisna zrilist: monohrafiia. [in Ukrainian].

УДК 159.922.8

doi: 10.15330/psp.24.48-58

Людмила Іванцев, Наталія Іванцев

\section{СТРАТЕГІЯ ЖИТТЯ ОСОБИСТОСТІ ТА МОЖЛИВОСТІ ÏÏ ПОБУДОВИ ЯК ПРЕДМЕТ ТЕОРЕТИКО-МЕТОДОЛОГІЧНОГО АНАЛІЗУ}

Стаття присвячена надзвичайно актуальній і важливій проблемі - стратегії життя особистості, яка визначається як модель побудови особистістю свого життя згідно зі власними иілями, зумовленими суспільними ичілями $і$ вимогами, а також можливостями реального здійснення ичих иілей. Аналізуються основні наукові підходи до вивчення проблеми життєвих стратегій особистості у світлі сучасних досліджень. Розглядається прочес формування і трансформаиіі життєвої стратегії особистості, ї̈ основні характеристики та типологія. Означуються можсливості побудови особистістю власної жстттвої cmpameziï.

Ключові слова: стратегія життя, пасивно-адаптивний тип життєвої стратегії, активний тип життєвої стратегії, життєва програма, життєва перспектива.

The article presents the scientific research results of the life strategy concept of the individual. The possibilities of life strategy formation of the individual are discussed. The topic relevance and the need for its further, more detailed, theoretical and methodological development, taking into account the modern social context are highlighted based on scientific generalization and systematization sources.

Based on the fundamental concept, life strategy is defined as an individual's life formation model according to own goals, determined by social goals and requirements as well as the possibilities of real fulfilment of these goals.

(С) Іванцев Л., Іванцев Н., 2019.

Збірник наукових праць: психологія.

Вип. 24. С. $48-58$ 